\title{
Peran Modal Sosial dalam Melestarikan Subak Bukti Batan Badung di Desa Gulingan Kecamatan Mengwi Kabupaten Badung
}

\author{
I GUSTI PUTU SASTRA PUTRA KUSUMA, \\ I WAYAN WINDIA, NI WAYAN SRI ASTITI \\ Program Studi Agribisnis, Fakultas Pertanian, Universitas Pertanian \\ J1. PB. Sudirman Denpasar 80323 \\ E-mail: sastraputrakusuma@yahoo.com \\ wayanwindia@ymail.com
}

\begin{abstract}
Role of Social Capital in Preserving Subak Bukti Batan Badung in Gulingan Village, Mengwi Sub-district, Badung Regency
\end{abstract}

Subak Bukti Batan Badung is one of the subaks found in Bali. The area of Subak Bukti Batan Badung was previously 65,25 hectares and had undergone land conversion of 7,25 hectares. Seeing the current development, it is highly likely that the existence of Subak Bukti Batan Badung could be threatened. Thus, there is a need for the role of social capital is preserving Subak Bukti Batan Badung. The data analysis method used was descriptivr qualitative. The results of this study showed that social capital owned by Subak Bukti Batan Badung to keep its sustainability was good which could be seen in: (1) the farmer's belief in other farmers, the farmer's belief in subak administrators, farmer's belief in the government program and religious rituals, and the farmer'e belief in the cooperatives, (2) the norms; awig-awig owned was not strong enough to suppress land conversion. Other norms were still strong and obeyed by all the subak member. (3) The social network owned could br said to be good, it could be seen from subak's relationship with banjar/adat village, subak relationship with Public Work and Agricultural Departements. The suggestion that can be made from this research is to reinforce regulation accompanied bu sanction for related parties violating the awig-awig and awareness of subak members not to do land conversion.

Keywords: conservation, social capital, land conversion, and subak.

\section{Pendahuluan}

\subsection{Latar Belakang}

Keberadaan subak yang sudah hampir satu milineum sampai sekarang ini mengisyaratkan bahwa subak adalah sebuah lembaga irigasi tradisional yang tangguh dan lestari. Salah satu ancaman terbesar kelestarian subak semakin banyaknya sawah yang hilang karena alih fungsi ke non pertanian. Begitu pula 
yang terjadi di Subak Bukti Batan Badung merupakan salah satu subak yang terletak di Desa Gulingan, Kecamatan Mengwi, Kabupaten Badung yang masih tetap lestari sampai sekarang meskipun sudah banyak sawah yang dialih fungsikan ke non pertanian. Luas Subak Bukti Batan Badung dulunya 65.25 hektar, seiring berjalannya waktu akibat alih fungsi lahan kini luas Subak Bukti Batan Badung hanya 58 hektar. Melihat perkembangan saat ini tidak menutup kemungkinan bahwa nantinya keberadaan Subak Bukti Batan Badung bisa terancam kelestariannya. Dengan demikian, perlu adanya peran modal sosial dalam melestarikan Subak Bukti Batan Badung. Modal sosial (social capital) dapat didefinisikan sebagai kemampuan masyarakat untuk bekerja bersama di dalam berbagai kelompok dan organiasasi (Field, 2009).

Modal sosial yang mendukung dalam melestarikan Subak Bukti Batan Badung diukur dari tiga komponen yaitu komponen kepercayaan yang diukur adalah kepercayaan petani terhadap petani lainnya, kepercayaan anggota subak terhadap pengurus subak, kepercayaan petani terhadap program pemerintah, kepercayaan petani terhadap ritual keagamaan, dan kepercayaan petani terhadap koperasi. Komponen norma yang diukur adalah pelaksanaan rapat bulanan, implementasi dan sanksi dari peraturan (awig-awig) subak, larangan untuk alih fungsi lahan, dan pengaturan air irigasi. Komponen jaringan sosial yang diukur adalah hubungan subak dengan banjar/desa adat, dan hubungan subak dengan PU atau Dinas Pertanian.

\subsection{Rumusan Masalah}

Berdasarkan latar belakang di atas, maka dapat dirumuskan masalah yaitu bagaimana peran modal sosial dalam melestarikan Subak Bukti Batan Badung dari komponen kepercayaan, norma, dan jaringan sosial?

\subsection{Tujuan Penelitian}

Adapun tujuan dari penelitian ini untuk mengetahui peran modal sosial dalam melestarikan Subak Bukti Batan Badung dari komponen kepercayaan, norma, dan jaringan sosial.

\section{Metode Penelitian}

\subsection{Lokasi dan Waktu Penelitian}

Lokasi penelitian dilaksanakan di Subak Bukti Batan Badung, di Kecamatan Mengwi, Kabupaten Badung. Pemilihan lokasi penelitian dipilih secara sengaja (purposive). Waktu pengumpulan data sekunder dan data primer berlangsung dari bulan Januari sampai dengan Juli 2017. Pertimbangan pemilihan lokasi penelitian ini sebagai berikut.

1. Subak Bukti Batan Badung merupakan subak yang terletak diDesa Gulingan,Kecamatan Mengwi, Kabupaten Badung yang masih tetap lestari dari dulu hingga sekarang meskipun adanya alih fungsi lahan.

2. Pihak pengurus Subak Bukti Batan Badung bersikap terbuka sehingga data yang diperlukan dalam penelitian ini mudah untuk didapat.

3. Belum pernah dilakukan penelitian serupa di Subak Bukti Batan Badung. 


\subsection{Sumber dan Jenis Data}

Sumber data dalam penelitian ini meliputi data primer dan data sekunder. Jenis data terdiri dari data kualitatif dan data kuantitatif. Data primer diperoleh dari hasil wawancara mendalam dengan informan kunci menggunakan pedoman wawancara. Wawancara dengan informan kunci menggunakan pedoman wawancara. Informasi langsung dari pekaseh, kelihan munduk, dan anggota subak. Data sekunder meliputi literatur, artikel, jurnal, situs di internet, gambaran umum daerah penelitian, dan kelembagaan Subak Bukti Batan Badung. Data kualitatif menjelaskan mengenai peran modal sosial dalam melestarikan Subak Bukti Batan Badung. Data kuantitatif berupa jumlah anggota, luas areal subak, dan lain-lain.

\subsection{Informan Kunci}

Informan ditentukan berdasarkan teknik purposive (sengaja) yang dianggap mampu menjawab tujuan penelitian ini. Menurut Sugiyono (2009), penentuan sampel atau informan dalam penelitian kualitatif berfungsi untuk mendapatkan informasi yang maksimum, karena itu orang yang dijadikan sampel atau informan sebaiknya yang memenuhi kriteria sebagai berikut.

1. Anggota subak yang masih aktif

2. Mereka yang menguasai dan memahami dengan baik keadaan Subak Bukti Batan Badung

3. Mereka mempunyai cukup waktu untuk diwawancarai

Pengambilan informan dilakukan secara sengaja karena dianggap paling tahu tentang apa yang penulis harapkan. Pada penelitian ini diambil responden penelitian yaitu.

1. Bapak I Ketut Wena, Pekaseh Subak Bukti Batan Badung

2. Bapak, I Made Lantika, Sekretaris Subak Bukti Batan Badung

3. Bapak, I Nyoman Ramia,Kelihan tempek Bukti Tuh

4. Bapak, I Gusti Made Jaya, Anggota Subak

5. Bapak I Gusti Putu Ardha, Anggota Subak

\subsection{Pengumpulan Data}

Pengumpulan data dalam penelitian ini melalui observasi, wawancara mendalam, Focus Group Discussion (FGD), dan dokumentasi. Wawancara mendalam (indepth interview) dilakukan dengan informan kunci yang telah ditentukan dengan menggunakan instrumen penelitian yaitu, pedoman wawancara yang diberikan kepada informan sebanyak lima orang, sedangkan focus group discussion merupakan suatu proses pengumpulan informasi mengenai suatu masalah tertentu yang sangat spesifik (Ibrahim, 2015), kegiatan tersebut dilakukan dengan tujuh orang untuk memvalidasi data dari hasil wawancara mendalam. Observasi dilakukan untuk mengetahui keadaan langsung di Subak Bukti Batan Badung. Dokumentasi dapat berupa foto-foto keadaan wilayah penelitian dan pada saat kegiatan kegiatan wawancara dengan informan. 


\subsection{Analisis Data}

Analisis data menggunakan analisis deskriptif kualitatif yang diperoleh dari hasil observasi, wawancara mendalam, FGD, dan dokumentasi. Analisis data dilakukan dengan tiga langkah yaitu: pengumpulan data, kalsifikasi data, interpretasi data, dan penarikan kesimpulan akhir (Ibrahim, 2015). Pertama, menghimpun data sebanyak mungkin di lapangan. Kedua, data-data yang telah dikumpulkan diklarifikasi sesuai dengan tematik atau aspek kajian yang telah ditentukan dalam penelitian ini. Ketiga, pada akhirnya data-data yang sudah diklarifikasi dalam tema/aspek penelitian ditafsirkan dan dimaknai sebagai sebuah kesimpulan akhir dari penelitian ini.

\section{Gambaran Umum Lokasi Penelitian}

\subsection{Deskripsi Subak Bukti Batan Badung}

Subak Bukti Batan Badung merupakan subak yang terletak di wilayah Desa Gulingan, Kecamatan Mengwi, Kabupaten Badung. Batas wilayah bagian utara adalah Subak Bulan, bagian barat adalah Telabah Taep, bagian selatan adalah Subak Beringkit, dan bagian timur adalah Tukad Dangkan. Luas areal sawah pada Subak Bukti Batan Badung seluas 58 hektar. Adapun stuktur organisasi Subak Bukti Batan Badung dapat dilihat pada Gambar 1.

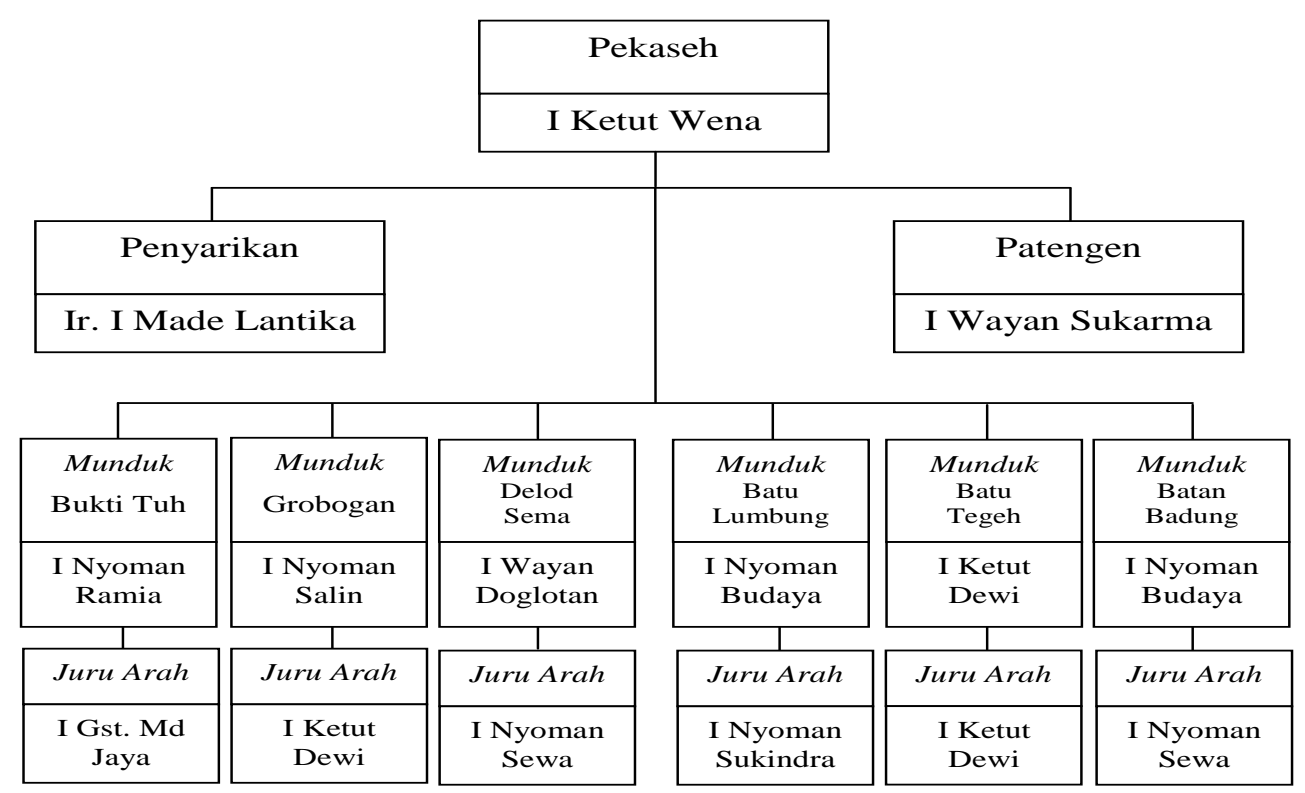

Gambar 1.

Stuktur Organisasi Subak Bukti Batan Badung Tahun 2016

Sumber: Profil Subak Bukti Batan Badung, Tahun 2016

\section{Hasil Dan Pembahasan}

\subsection{Modal Sosial dalam Melestarikan Subak Bukti Batan Badung}

Keberadaan Subak Bukti Batan Badung yang semakin lama semakin terancam kelestariannya karena banyak lahan yang beralih fungsi ke non pertanian. Subak Bukti 
Batan Badung masih tetap dapat menjaga kelestariannya karena Subak Bukti Batan Badung mampu memanfaatkan modal sosial yang dimiliki.

Modal sosial sosial memiliki tiga komponen penting yaitu kepercayaan, norma, dan jaringan sosial. Modal sosial yang dimiliki oleh Subak Bukti Batan Badung menjadi pendukung utama untuk tetap menjaga kelestarian Subak Bukti Batan Badung. Subak Bukti Batan Badung berhasil memanfaatkan modal sosial yang dimiliki yang tercermin dari adanya kepercayaan, norma, dan jaringan sosial.

\subsection{Komponen Kepercayaan}

Peran modal sosial dalam melestarikan Subak Bukti Batan Badung dilihat dari komponen kepercayaan dapat dijelaskan sebagai berikut.

1. Kepercayaan petani terhadap petani lainnya

Kepercayaan petani dengan petani lainnya di Subak Bukti Batan Badung sangat baik dapat dilihat dari pengaturan air irigasi. Terdapat kepercayaan yang baik antar petani terhadap petani lainnya yang diwujudkan oleh adanya saling pinjam meminjam air irigasi pada saat air irigasi dalam kondisi sulit atau musim kemarau atas ijin petani yang sudah selesai menggunakan air. Petani satu dengan yang lainnya selalu tertib dan taat pada aturan atau arahan yang diberikan pada kelian tempek atau pekaseh khususnya pada kegiatan pengolahan air irigasi.

2. Kepercayaan petani terhadap pengurus subak

Kepercayaan anggota subak terhadap pengurus subak di Subak Bukti Batan Badung dipercayai sepenuhnya oleh anggota subak dan selalu didukung oleh anggota subak. Seluruh anggota Subak Bukti Batan Badung sepenuhnya percaya dengan pengurus subak baik dalam pengelolaan keuangan subak dan kegiatan subak lainnya. Pengurus subak selalu bersifat transparan, memaparkan seluruh keuangan subak baik dana yang masuk atau dana yang keluar untuk kegiatan subak seperti odalan di Pura Subak dan biaya perawatan saluran irigasi jika terjadinya kerusakan yang tidak terlalu besar dan masih bisa diperbaiki oleh subak. Pada saat dilaksanakannya kegiatan rapat subak, sebagian besar anggota subak selalu mendengarkan dengan baik apa yang disampaikan oleh pengurus subak.

\section{Kepercayaan petani terhadap program pemerintah}

Kepercayaan petani dengan program pemerintah terlihat pada adanya bantuan dana dan subsidi pupuk dan benih dari provinsi dan juga kabupaten yang bertujuan untuk mensejahterakan krama subak dan juga untuk tetap menjaga kelestarian subak. Adanya kepercayaan petani terhadap program pemerintah dengan diberikannya subsidi pupuk dan bibit kepada seluruh anggota subak yang nantinya akan berpengaruh kepada kesejahteraan petani dan kelestarian subak khususnya Subak Bukti Batan Badung. Kepercayaan lainnya terdapat pada bagaimana petani dalam menjalankan program 
tersebut agar berjalan dengan baik begitu juga pemerintah yang nantinya akan terus memberikan bantuan-bantuan ke subak.

\section{Kepercayaan petani terhadap ritual keagamaan}

Upacara keagamaan tetap dilakukan oleh seluruh anggota Subak Bukti Batan Badung dari masa ke masa maupun dari generasi ke generasi berikutnya. Kegiatan ritual Subak Bukti Batan Badung dilakukan secara kolektif (bersama) dan individual (perorangan). Secara kolektif dilaksanakan berdasarkan fase-fase pertumbuhan padi, sedangkan secara individual berdasarkan rerahinan dan sesajennya. Kegiatan ritual keagamaan yang dilakukan secara kolektif dan dilakukan secara rutin meliputi magpag toya, ngendagin, ngurit, ngewiwit, nuasen nandur (memula), nyungsung, biyukukung, mebanten manyi (nuduk dewa nini), dan mantenin sedangkan kegiatan ritual keagamaan yang tidak dilakukan secara rutin (insidental) meliputi masudi dan ngerasakin. Kepercayaan petani dengan ritual keagamaan di Subak Bukti Batan Badung masih tetap dilakukan tanpa meninggalkan satupun ritual kegamaan dari dulu hingga sekarang.

\section{Kepercayaan petani terhadap koperasi}

Subak Bukti Batan Badung memiliki Koperasi Tani Manik Sari yang berdiri sejak tahun 2007. Koperasi tersebut merupakan bagian dari swadaya masyarakat untuk kesejahteraan anggotanya dengan memberikan dana atau modal usaha melalui simpan pinjam bagi anggota subak ataupun masyarakat yang membutuhkan. Tersedianya kelembagaan usaha atau koperasi di Subak Bukti Batan Badung membantu anggota subak dalam mendukung usahataninya sehingga tidak ada lahan persawahan yang terbengkalai akibat tidak adanya modal petani dalam melakukan usahataninya. Sejak berdirinya koperasi subak, petani lebih mudah dalam mengelola lahan pertanian mereka dari segi permodalan dan sawah milik petani juga tidak ada yang terbengkalai.

\subsection{Komponen Norma}

Peran modal sosial dalam melestarikan Subak Bukti Batan Badung dilihat dari komponen norma dapat dijelaskan sebagai berikut.

\section{Pelaksanaan rapat subak}

Rapat subak dilakukan setiap tiga bulan sekali yang membahas tentang rencana tanam, penggunaan varietas, penyediaan kebutuhan sarana produksi, dan membahas keuangan subak. Rapat insidental juga dilakukan jika ada permasalah di Subak Bukti Batan Badung dan jika ada program dari pemerintah. Jumlah anggota Subak Bukti Batan Badung yang hadir dalam setiap rapat kehadirannya mencapai 90\%. Bagi anggota yang tidak hadir dikenakan sanksi berupa uang yang berjumlah Rp.15.000 dan di bayar saat rapat yang akan datang. Rapat subak merupakan salah satu mekanisme dan upaya 
Subak Bukti Batan Badung dalam menjaga komunikasi antara petani dengan petani lainnya yang akan berperan penting dalam melestarikan Subak Bukti Batan Badung kedepannya.

2. Implementasi dan sanksi dari awig-awig dan pararem subak

Subak Bukti Batan Badung menerapkan sanksi dari awig-awig dan pararem subak berupa denda sebesar 5.000,- per kegiatan subak jika tidak hadir dalam kegiatan subak seperti gotong-royong dalam pembersihan saluran irigasi dan ngayah di Pura Subak. Penerapan sanki dari awig-awig subak terdapat hal yang menarik yaitu jika ada anggota subak yang menjual lahan atau melakukan alih fungsi lahan dikenakan sanksi berupa beras $25 \mathrm{~kg}$ per are dan melakukan upacara keagamaan (bermakna mengembalikan Dewi Sri ke Pura Subak).

\section{Larangan alih fungsi lahan}

Alih fungsi lahan sampai saat ini mencapai 7,25 Ha dari semula luas subak Bukti Batan Badung 65,25 Ha menjadi $58 \mathrm{Ha}$. Subak berupaya menekan alih fungsi lahan ini dengan cara menyarankan pemilik lahan untuk tidak menjual lahannya tetapi memilih mengontrakannya jika dalam keadaan terpaksa. Terdapat awig-awig di Subak Bukti Batan Badung yang melarang untuk melakukan alih fungsi lahan, tetapi kekuatan awigawig tidak cukup kuat karena masih sebatas himbauan saja. Sanksi berupa beras $25 \mathrm{~kg}$ per are dan wajib melakukan upacara keagamaan Nyiwi (mengembalikan Dewi Sri ke Pura Subak) diterapkan di Subak Bukti Batan Badung jika ada anggota subak yang melakukan alih fungsi lahan atau menjual lahan pertaniannya.

\section{Pengaturan air irigasi}

Mengatur maupun mengawasi pembagian air di Subak Bukti Batan Badung merupakan tugas pokok Pekaseh dan Kelihan Munduk. Kelihan Munduk juga melakukan pengontrolan air irigasi di munduknya. Kelihan Munduk akan memimpin kegiatan gotong royong jika ditemui kerusakan atau saluran irigasi yang tersumbat. Pengaturan air irigasi di Munduk Bukti Tuh dipengaruhi oleh musim, dimana pada musim hujan Munduk Bukti Tuh mendapatkan air irigasi dan memungkinkan untuk melakukan usaha tani, sebaliknya pada musim kemarau Munduk Bukti Tuh sangat sulit untuk mendapatkan air irigasi karena Munduk Bukti Tuh bertempatan paling hilir dan sangat jauh dari saluran air utama.

\subsection{Komponen Jaringan Sosial}

Peran modal sosial dalam melestariakan Subak Bukti Batan Badung dilihat dari komponen jaringan sosial dapat dijelaskan sebagai berikut.

1. Hubungan subak dengan banjar/desa adat 
Terdapatnya hubungan yang baik antar seluruh anggota subak dengan pihak banjar/desa adat yang terlihat pada keikut sertaan pihak banjar/desa adat dalam melakukan gotong royong dalam setiap pembuatan sarana upacara di Pura Subak. Keikutsertaan banjar/desa adat dalam setiap kegiatan subak mencerminkan adanya hubungan sosial yang baik antara subak dengan banjar/desa adat. Kegitan ngayah di subak dalam pembuatan sarana upacara yang dilakukan oleh ibu-ibu PKK dengan membuat banten yang akan digunakan pada saat odalan (upacara keagamaan) di Pura Bedugul (Pura Subak) menjadi bukti bahwa adanya hubungan baik antar anggota subak dengan banjar/desa adat. Krama lainnya juga turut membantu dalam pembuatan sarana upacara seperti membuat sate, memotong babi, membuat lawar, membuat penjor, memasang kain di Pura Subak, dan melakukan gotong royong yang dilakukan disekitaran Subak Bukti Batan Badung.

\section{Hubungan subak dengan Dinas PU/Dinas Pertanian}

Adanya hubungan antara subak dengan Dinas PU (Pekerjaan Umum) yang dimana dinas PU selalu memperhatikan Subak Bukti Batan Badung dalam segi pembangunan yaitu saluran irigasi. Dinas PU juga ikut berperan penting dalam melestarikan subak melalui pembangunan saluran irigasi yang dimana jika saluran irigasi baik maka pengguanaan air irigasi nantinya akan berjalan lancar dan petani mendapatkan hasil panen yang maksimal. Hubungan sosial antara subak dengan Dinas PU terlihat dimana subak mendapatkan perhatian dalam pembangunan saluran irigasi yang diharapkan agar kelestarian subak tetap terjaga. Dinas Pertanian juga memberikan bantuan berupa pupuk bersubsidi dan bibit unggul yang setidaknya dapat mengurangi beban petani dari segi modal dalam bertani.

\section{Simpulan dan Saran}

\subsection{Simpulan}

Berdasarkan hasil dari penelitian seperti yang sudah dibahas pada bab sebelumnya dapat disimpulkan beberapa hal pokok sebagai berikut.

\section{Kepercayaan}

Peran modal sosial dalam melestarikan Subak Bukti Batan Badung dilihat dari komponen kepercayaan yang dimiliki dapat dikatakan sudah baik, hal ini terlihat dari adanya: (a) kepercayaan petani terhadap petani lainnya, (b) kepercayaan anggota subak terhadap pengurus subak, (c) kepercayaan petani terhadap program pemerintah, (d) kepercayaan petani terhadap ritual keagamaan, dan (e) kepercayaan petani terhadap koperasi.

\section{Norma}

Peran modal sosial dalam melestarikan Subak Bukti Batan Badung dilihat dari komponen norma menunjukan bahwa di Subak Bukti Batan Badung terdapat awig-awig yang melarang untuk alih fungsi lahan. Akan tetapi, awig-awig 
tersebut belum cukup kuat untuk menekan alih fungsi lahan karena awig-awig tersebut hanya sebatas himbauan. Norma lainnya yang dimiliki oleh Subak Bukti Batan Badung masih tetap kuat dan dipatuhi oleh seluruh anggota subak.

\section{Jaringan Sosial}

Peran modal sosial dalam melestarikan Subak Bukti Batan Badung dilihat dari komponen jaringan sosial yang dimiliki dapat dikatakan sudah baik. Hal ini terlihat dari: (a) hubungan subak dengan banjar/desa adat dan (b) hubungan subak dengan Dinas PU dan Dinas Pertanian.

\subsection{Saran}

Berdasarkan pembahasan hasil penelitian dan kesimpulan maka saran yang dapat diberikan penulis terkait dengan penelitian ini sebagai berikut.

1 Peran modal sosial dalam melestarikan Subak Bukti Batan Badung dilihat dari komponen kepercayaan yang dimiliki dapat dikatakan sudah baik, hal ini perlu dipertahankan dan bila perlu agar ditingkatkan.

2 Awig-awig yang ada di Subak Bukti Batan Badung belum cukup kuat untuk menekan alih fungsi lahan karena awig-awig hanya dianggap sebatas himbauan, sehingga dalam penerapannya diperlukan kesadaran dari masing-masing anggota subak akan pentingnya mematuhi awig-awig agar keberadaan Subak Bukti Batan Badung tetap terjaga kelestariannya. Regulasi diperkuat yang disertai dengan sanksi untuk pihak-pihak terkait yang melanggar awig-awig tersebut. Pemerintah juga harusnya memberikan reward bagi petani yang masih mempertahankan sawahnya. Perda dan awig-awig tertulis juga ikut mengatur jika ada transaksi jual beli lahan pertanian. Norma lainnya yang dimiliki oleh Subak Bukti Batan Badung masih tetap kuat dan dipatuhi oleh seluruh anggota subak, dimana hal ini tentunya perlu untuk dipertahankan.

3 Peran modal sosial dalam melestarikan Subak Bukti Batan Badung dilihat dari komponen jaringan sosial yang dimiliki dapat dikatakan sudah baik, sehingga penting untuk dipertahankan, dimana komunikasi antar masyarakat yang ada di subak serta komunikasi subak dengan Dinas PU dan Dinas Pertanian atau instansi terkait lainnya dapat ditingkatkan agar tercapainya kebersamaan dan kesuksesan dalam melestarikan Subak Bukti Batan Badung.

\section{Ucapan Terimakasih}

Ucapan terimakasih ini penulis tunjukan kepada seluruh pengurus dan angota Subak Bukti Batan Badung, yang telah membantu dalam pelaksanaan penelitian hingga karya ilmiah ini dapat di publikasikan di e-jurnal. 


\section{Daftar Pustaka}

Budiastuti, Putu. 2015. Upaya Pelestarian Subak di Perkotaan. Skripsi. Fakultas Pertanian Universitas Udayana.

Field, Jhon. 2009. Modal Sosial. Kreasi Wacana, Yogyakarta.

Ibrahim, M.A. 2015. Metodelogi Penelitian Kualitatif. Alfabeta, Bandung.

Peraturan Daerah Provinsi Bali No. 9 tahun 2012 tentang Subak

Pitana, I Gde dan I Gede Setiawan (Editor) 2005. Revitalisasi Subak Dalam Memasuki Era Globalisasi. Yogyakarta: Penerbit Andi.

Sugiyono. 2012. Memahami Penelitian Kualitatif. Alfabeta, Bandung.

Sutawan, Nyoman. 2008. Organisasi dan Manajemen Subak di Bali. Denpasar: Pustaka Bali Post.

Sudarta, Wayan. 2016. Sosiologi Pertanian. Udayana University Press, Denpasar

Windia, Wayan. Dkk.2015.Sistem Subak Di Bali (Kajian Sosiologi). Udayana University Press, Denpasar

Windia, Wayan. 2006. Transformasi Sistem Irigasi Subak yang Berlandaskan Tri Hita Karana. Denpasar: Pustaka Bali Post. 